\title{
PERANAN KOMUNITAS LOKAL DALAM PERENCANAAN PENGEMBANGAN GEOSITE DI KAWASAN GEOPARK BELITONG
}

\author{
Yuspian Djapani ${ }^{1}$ \\ Nana Sulaksana ${ }^{2}$ \\ Budi Muljana ${ }^{3}$ \\ ${ }^{1}$ Pemda Belitung Timur \\ ${ }^{2}$ Program studi Regional Inovasi Sekolah Pascasarjana Universitas Padjadjaran \\ ${ }^{3}$ Fakultas Teknik Geologi Univesitas Padjadjaran \\ Email: yuspiandj@gmail.com
}

\begin{abstract}
Abstrak
Penelitian ini bertujuan untuk mengetahui bagaimana masyarakat setempat sebagai pengelola geosite membuat perencanaan pengembangan geosite di Kawasan Geopark Belitong. Dalam hal ini masyarakat setempat menjadi sumber utama informasi penelitian. Metode penelitian yang digunakan adalah studi deskriptif dengan pendekatan kualitatif. Penelitian ini tidak didasarkan pada pengujian hipotetis tetapi dengan menggunakan analisis terhadap definisi operasional konsep yang telah dirumuskan berdasarkan pertanyaan penelitian. Namun demikian, peneliti juga melakukan analisis matematika menggunakan Teknik "Weight Scoring System" atau sistem penilaian berbobot untuk menganalisis pola dan arti hubungan antar kategori. Sementara itu, peninjauan literatur masih tetap dilakukan untuk mengetahui teori-teori yang telah diterapkan dalam penelitian terkait. Instrumen pengumpulan data menggunakan teknik observasi, dokumentasi, dan wawancara. Penelitian ini dilakukan di 4 (empat) lokasi Geosite yang terdiri dari 1) Geosite Bukit Peramun di Kecamatan Sijuk Kabupaten Belitung, 2) Geosite Juru Sebrang di Kecamatan Tanjungpandan Kabupaten Belitung, 3) Geosite OpenPit Namsalu di Kecamatan Kelapa Kampit Kabupaten Belitung Timur dan 4) Geosite Tebat Rasau di Kecamatan Simpang Renggiang Kabupaten Belitung Timur. Dengan teknik "purposive sampling", maka jumlah Informan yang digunakan adalah sebanyak 16 orang yang didistribusikan secara proporsional untuk setiap lokasi penelitian. Penelitian ini menemukan fakta bahwa masyarakat lokal pada umumnya memiliki kemampuan yang baik untuk menyusun dan merumuskan perencanaan pengembangan Geosite namun tetap berpotensi untuk lebih ditingkatkan dengan mengoptimalkan pengetahuan, partisipasi dan keterampilan teknis dalam perencanaan melalui strategi peningkatan kapasitas sumber daya manusia (HRD) dalam pengelolaan Geosite sesuai dengan top 10 fokus area UNESCO Global Geopark.
\end{abstract}

Kata Kunci: Komunitas lokal, Perencanaan Partisipatif, Pengembangan Geosite, Geopark Belitong, Geowisata 


\begin{abstract}
This research is aimed to determine how the local community as geosite operator in making geosite development planning in Belitong Geopark. The research method is a descriptive study with a qualitative approach where the local community becomes the main source of research information. This research is not based on hypothetical but operational definition concepts analysis that have been formulated based on research questions. However, the mathematical analysis is used through the "Weight Scoring System" Technique or weighted assessment system to analyze the patterns and meaning of relationships between the categories. Meanwhile, a review of the literature is still undertaken to determine the theories that have been applied in related research. Data is collected by the observation techniques, documentation, and interviews. This research was conducted in 4 (four) Geosite locations: 1) Bukit Peramun Geosite in Sijuk SubDistrict of Belitung Regency, 2) Juru Sebrang Geosite in Tanjungpandan SubDistrict of Belitung Regency, 3) OpenPit Namsalu Geosite in Kelapa Kampit SubDistrict of East Belitung Regency and 4) Tebat Rasau Geosite in Simpang Renggiang Sub-District of East Belitung Regency. With the purposive sampling technique, there are 16 respondents that are distributed in proportionately for every research location. The study have found that local communities generally have a good ability to structure and formulate Geosite development planning but still have to enhance in the future by optimizing knowledge, participation and development planning skill through human resource development (HRD) strategies in geosite management in accordance with the top 10 focus area of UNESCO Global Geopark.
\end{abstract}

Keywords: Local Community, Participatory Planning, Geosite Development, Belitong Geopark, Geotourism

\title{
PENDAHULUAN
}

Geopark merupakan suatu kawasan yang dikembangkan dengan kegiatan konservasi, edukasi dan pemberdayaan ekonomi masyarakat melalui pemanfaatan tiga unsur penting sebagai "pilar" utama berupa potensi "warisan geologi" (geological heritage), "keragaman geologi" (biological diversity) dan "keragaman budaya (culture diversity)" dimana ketiga unsur tersebut saling berkaitan serta dirumuskan menjadi keunikan yang dapat menjadi ciri sekaligus strategi dalam pengembangan suatu wilayah. Menurut UNESCO Global Geopark (UGGp), Geopark memiliki makna;

"UNESCO Global Geoparks are single, unified geographical areas where sites and landscapes of international geological significance are managed with a holistic concept of protection, education and sustainable 
development. A UNESCO Global Geopark uses its geological heritage, in connection with all other aspects of the area's natural and cultural heritage, to enhance awareness and understanding of key issues facing society, such as using our earth's resources sustainably, mitigating the effects of climate change and reducing natural disasters-related risks. By raising awareness of the importance of the area's geological heritage in history and society today, UNESCO Global Geoparks give local people a sense of pride in their region and strengthen their identification with the area. The creation of innovative local enterprises, new jobs and high quality training courses is stimulated as new sources of revenue are generated through geotourism, while the geological resources of the area are protected" (UNESCO Global Geoparks, 2017)

Pulau Belitung mulai mengenal dan menerapkan konsep pengembangan Pariwisata berbasis Geopark pada akhir tahun 2016, Pengenalan konsep Geopark memunculkan pemahaman baru bagi Pemerintah Daerah dan masyarakat tentang adanya kesamaan identitas yang "memungkinkan" penyatuan konsep pengembangan pariwisata antar dua kabupaten di Pulau Belitung yaitu Kabupaten Belitung dan Kabupaten Belitung Timur, yaitu dengan adanya "kesamaan" warisan geologi yang sangat bernilai (Outstanding) untuk dikembangkan bersama antara lain; 1) Batu Satam (Billitonite Tektite), 2) Adanya lanskap Batuan Granit berukuran besar (TOR Granit), dan 3) Adanya warisan sejarah tambang timah yang hingga saat ini masih dapat dijumpai sebagai bekas lokasi pertambaangan timah yang sekaligus menggambarkan sejarah teknologi tambang timah di masa lampau. Keberadaan situs warisan Geologi tersebut memberikan pemahaman tentang pariwisata berbasis warisan geologi dan lanskap alam atau disebut dengan istilah "Geotourism” yang didefinisikan sebagai "(Geotourism is) associated with tourism earth-sciences and is well known in the tourism industry as a tourism activity with focus on geologi and natural landscape" (Anze Chen, 2015).

Selain memiliki warisan geologi Pulau Belitung juga memiliki keanekaragaman hayati baik hewan maupun tumbuhan yang unik dan khas, misalkan adanya Ekosistim Hutan Kerangas yang merupakan karakter hutan diatas tanah yang "miskin" unsur hara, sehingga terdapat berbagai jenis tanaman yang khas yang sebagian besar merupakan tanaman obat, termasuk dalam hal ini adanya jenis hewan Tarsius Belitong yang oleh masyarakat lokal desebut Pelile'an 
juga memperkaya keanekaragaman hayati Pulau Belitung. Dari aspek keragaman budaya Pulau Belitong juga memiliki kultur sebagai masyarakat tambang khususnya tambang timah disamping memiliki ciri sebagai masyarakat melayu pesisir sesuai dengan karakteristik daerah kepulauan. Selain itu Pulau Belitung juga dikenal sebagai jalur pelayaran internasional sejak masa lampau bahkan sejak zaman kekaisaran china pertama (Dinasti Tang) hal ini terbukti dengan banyaknya situs kapal kuno (Shipwreck) berasal dari zaman kekaisaran China yang tenggelam sekitar perairan Pulau Belitung.

Saat ini Terdapat sebanyak 17 (tujuh belas) Geosite yang masuk dalam manajemen pengelolaan Geopark Belitong dengan keunikan Geologi, Biologi maupun Budaya yang beragam dan potensial untuk dikembangkan, terdiri dari; 1) Geosite Juru Sebrang 2) Geosite Desa Wisata Terong, 3) Geosite Hutan Magrove Kuale, 4) Geosite Bukit Peramun, 5) Geosite Tanjung Kelayang, 6) Geosite Batu Bedil, 7) Geosite Open pit Nam Salu, 8) Geosite Batu Pulas, 9) Geosite Gunung Lumut, 10) Geosite Hutan Kerangas Cendil, 11) Geosite Burung Mandi, 12) Geosite Tanjung Siantu, 13) Geosite Gunung Tajam, 14) Geosite Batu Baginde, 15) Geosite Pantai Punai, 16) Geosite Tebat Rasau, dan 17) Geosite Garumedang (Billitonite Tektite) (Geosite Map, n.d.). Banyaknya jumlah Geosite yang tersebar di dua wilayah Kabupaten di Pulau Belitung, menjadikan pengelolaan Geosite memiliki peran yang sangat "strategis" karena memerlukan koordinasi dari berbagai stakeholder di kedua wilayah baik Pemerintah Daerah, Swasta maupun Masyarakat.

Saat ini Seluruh Geosite yang ada di wilayah Geopark Belitong dikelola oleh masyarakat setempat atau "komunitas lokal" dengan bentuk organisasi atau kelembagaan yang beragam, yaitu; 1) Masyarakat Pengelola Hutan Kemasyarakatan (HKm), 2) Kelompok Masyarakat Sadar Wisata (Pokdarwis), 3) Pemuda Karang Taruna Desa dan 4) Kelompok Organisasi Kemasyarakatan (Ormas).

Diperlukan kemampuan dan kapasitas yang mumpuni dalam merumuskan perencanaan pengembangan Geosite sebagai tahapan awal kegiatan pengembangan sekaligus tolak ukur keberhasilan pengembangan Geosite sesuai 
standar dan prinsip pengembangan Geopark Global sebagaimana 10 (sepuluh) prioritas pengembangan yang ditetapkan oleh UGGp terdiri dari; 1) Pemanfaatan Suberdaya Alam (Natural Resources), 2) Mitigasi Bahaya Geologi (Geological Hazard), 3) Perubahan Iklim (Climate Change), 4) Pendidikan (Education), 5) Ilmu Pengetahuan (Science), 6) Budaya (Culture), 7) Wanita (Women), 8) Pembangunan Berkelanjutan (Sustainable Development), 9) Pengetahuan Asli Masyarakat Lokal (Local and indigenous Knowledge), 10) Konservasi Gologi (Geoconcervation).

Sebagai sebuah organisasi yang memiliki tujuan bersama dalam pengembangan Geopark, komunitas pengelola Geosite harus memiliki fondasi yang kuat dalam menjalankan aktifitas, salah satu sarana agar sebuah organisasi dapat berjalan dengan baik dan sehat menurut para ahli adalah apa yang mereka sebut sebagai "azas-azas organisasi”. Selain itu partisipasi anggota dalam setiap kegiatan organisasi juga menjadi faktor kunci keberlangsungan sebuah organisasi oleh karena itu penelitian ini juga melakukan analisa berdasarkan teori "perencanaan partisipatif" yang dalam hal ini akan digunakan untuk menganalisa bagaimana bentuk-bentuk partisipasi yang dilaksanakan oleh anggota komunitas khususnya dalam merumuskan perencanaan pengembangan Geosite.

Untuk mengetahui lebih mendalam tentang bagaimana kemampuan komunitas dalam menyusun maupun merumuskan perencanaan pengembangan Geosite, maka dirumuskan tiga pertanyaan penelitian yaitu, Pertama; Bagaimana cara Komunitas membuat perencanaan untuk pengembangan Geosite di Kawasan Gepark Belitong?, kedua; Bagaimana bentuk keterlibatan komunitas dalam membuat perencanaan untuk pengembangan Geosite di Kawasan Geopark Belitong?, dan ketiga; Bagaimana kualitas pemahaman komunitas tentang Geopark dan peran Geositenya dalam pengembangan Geopark Belitong?.

Untuk menjawab pertanyaan penelitian tersebut metode penelitian yang digunakan adalah studi deskriptif dengan pendekatan kualitatif, Dalam hal ini peneliti adalah sebagai instrumen kunci. Pengambilan sampel sumber data dilakukan secara "purposive sampling", teknik pengumpulan data "Trianggulasi" bertujuan untuk memeriksa ke absahan data yang memanfaatkan data dan informasi yang lain untuk membandingkan hasil wawancara terhadap objek penelitian. 
Penelitian ini dilaksanakan di 4 (empat) lokasi dalam wilayah Geopark Belitong pertama; Geosite Bukit Peramun Kedua; Geosite Juru Sebrang, Ketiga; Geosite Open Pit Namsalu, Kabupaten Belitung Timur dan Keempat; Geosite Tebat Rasau. Untuk menjamin objektifitas penelitian maka informan ditentukan jumlahnya secara proporsional yaitu sebanyak 4 (empat) orang untuk setiap lokasi penelitian yang dianggap mewakili serta mampu memberikan gambaran fakta lapangan.

Adapun Teknik pengumpulan data yang digunakan adalah dengan; Observasi (Pengamatan), Wawancara (semi-structured interview) dan Dokumentasi. Sedangkan teknik analisa data yang digunakan adalah Teknik analisis data kualitatif yang sudah disederhanakan dari metode yang ditulis oleh pakar riset sosial Alan Bryman (Sosiologis.com, 2018), dengan tahapan: Koding, Membuat konsep, Membuat kategori, Membuat hipotesis dan Memperoleh hasil analisis.

\section{PEMBAHASAN}

\section{A. Profil Geosite lokasi penelitian}

1. Gesosite Juru Sebrang

Bentuk kelembagaan Geosite Juru Seberang adalah Kelompok Hutan Kemasyarakatan (HKm) merupakan kelompok masyarakat yang mengelola Kawasan hutan mangrove dan hutan pantai yang ada di Desa Juru Seberang, Kabupaten Belitung. Geosite Juru Sebrang diketuai oleh Marwandi dan memiliki unit usaha berbentuk koperasi yang bernama Kelompok Tani Seberang Bersatu, dengan wilayah kerja meliputi Desa Juru Seberang dan Teluk Dalam, Kecamatan Tanjung Pandan, Kabupaten Belitung. Koperasi ini mengelola semua kegiatan usaha yang ada di Kawasan HKm Seberang Bersatu meliputi kuliner, wisata, pertanian serta perikanan.

Dalam Kawasan HKm, dikembangkan atraksi wisata berupa; Belitong Mangrove Park (BMP) dengan dukungan dari Bappenas, KLKH, Terangi dan ICCTF untuk membangun infrastruktur dasar di BMP berupa jalur pejalan kaki. bantuan bibit mangrove dan program peningkatan SDM. BMP menawarkan 
aktifitas pada wisatawan seperti susur mangrove dengan jalan kaki, susur sungai dengan sampan, sewa sepeda, sunset view, penanaman bibit mangrove, kuliner Makan Bedulang, pengamatan burung, menangkap kerang bamboo (Ngijing), sylvofishery (memancing ikan di tambak). Area lain di kawasan HKm juga digunakan untuk bumi perkemahan dan kebun buah.

Sebagai Geosite Juru sebrang mengusung nilai keunikan geologi berupa lahan bekas tambang timah alluvial, nilai keanekaragaman hayati pada ekosistem mangrove dan budaya di mana Desa Juru Sebrang merupakan tempat pemukiman Suku Sawang.

2. Geosite Bukit Peramun

Geosite Bukit Peramun berlokasi di Desa Air Selumar, Kecamatan Sijuk, Kabupaten Belitung dengan mana komunitas pengelola ARSEL Community (Komunitas ARSEL). ARSEL Comunnity berdiri 28 Oktober 2008. Dengan semangat menjaga hutan dari tindakan pengrusakan seperti illegal logging dan keinginan mengelola sumber daya alam untuk kesejahteraan masyarakat, kelompok masyarakat yang diketuai oleh Adie Dermawan ini kemudian mengusulkan kawasan hutan Bukit Peramun menjadi Hutan Kemasyarakatan. Pada tahun 2013 mereka memiliki izin sebagai Hutan Kemasyarakatan $(\mathrm{HKm})$. Berselang empat tahun setelahnya, ARSEL mengembangkan Taman Kehati seluas 16.25 di kawasan Bukit Peramun.

Selama satu dekade, Kelompok Masyarakat ARSEL Community telah berkembang dengan tiga unit kerja yakni HKm ARSEL Community, Lembaga Pelatihan dan Pemagangan Usaha Kehutanan Swadaya (LP2UKS), Kerajinan Buah Bulin. ARSEL Community mengawarkan jasa wisata 6 (enam) hari dalam sepekan. Wisatawan bisa memilih program layanan yang tersedia diantaranya paket wisata edukasi, lintas alam tempat berkemah untuk pelajar, paket makan bedulang, Belitong Tarsius watching. Selain itu terdapat jasa lingkungan yang bekerja sama dengan beberapa perusahaan dalam program penanaman pohon. Melalui jasa wisata, produk ekonomi kreatif dan jasa lingkungan. 


\section{Geosite Openpit Nam Salu}

Geosite Open Pit Nam Salu dikelola oleh organisasi kemasyarakatan (Ormas) bernama Badan Pengelola Open Pit Nam Salu (BAPOPNAS) didirikan pada tahun 2018. Organisasi ini bertujuan untuk meningkatkan kesadaran masyarakat di bidang pariwisata, meningkatkan sumber daya manusia, mendorong terwujudnya Sapta Pesona, meningkatkan mutu produk wisata atau daya tarik wisata dalam rangka meningkatkan daya saing. Struktur organisasi BAPOPNAS memiliki 20 orang pengurus ini diketuai oleh Yusyarnubi dan dibimbing oleh Tino Christian dan Trisna Hardi sebagai penasehat senior. BAPOPNAS dalam menjalankan kegiatannya, sering kali melibatkan kelompok PKK dan Pemerintah Desa Senyubok. Penamaan Geosite Open Pit Nam Salu merujuk pada kawasan ekstambang terbuka (Open Pit) dan Nam Salu berarti urat selatan, sebagaimana penambang Hakka menamai area tersebut ketika bekerja sebagai buruh tambang untuk Kolonial Belanda.

Berdasarkan literatur Pusat Survei Geologi, kawasan Open Pit memiliki warisan geologi yang erat kaitannya dengan budaya dan sejarah penambangan Timah di Belitung diantaranya terdapat singkapan batuan formasi Kelapa Kampit pada tambang terbuka sedalam lebih dari 50 meter. Tampak bagaimana formasi bebatuan tertua di Pulau Belitung ini terbentuk dengan aneka ragam lipatan yang menjadi fenomena geologi. Selain itu terdapat juga tambang dalam timah (underground tin mining) tertua di Indonesia yang dibangun oleh Kolonial Belanda pada terowongan Fuk Salu yang kemudian pembangunan terowongan itu diteruskan oleh BHP untuk operasi tambang dalam dan drainase di Open Pit. Kawasan yang terletak di Bukit Kik Karak ini juga menyimpan kekayaan biodeverstias diantaranya Pohon Seruk, Pasak Bumi, Kantong Semar, berbagai jenis paku-pakuan dan lain sebagainya.

Dengan mengusung konsep Container Park, tersedia bangunan kontainer untuk sekretariat, toilet, mushala. Selain itu terdapat amenitas seperti gerbang, panel informasi, rambu peringatan dan penunjuk arah serta jalan tanah merah dan kawasan parkir. BAPOPNAS juga menawarkan berbagai program seperti jasa wisata, magang dan konservasi lahan bekas tambang. Semenjak 2018 sudah ratusan 
wisatawan nusantara dan mancanegara yang berkunjung di mana wisatawan mancanegara didominasi oleh pelancong dari Negeri Jiran.

\section{Geosite Tebat Rasau}

Komunitas Lanun Tebat Rasau merupakan Komunitas Pengelola Geosite Tebat Rasau, dibentuk pada awal 2018 dengan semangat untuk menjaga kelestarian Rawa Tebat Rasau dan Sungai Lenggang dimana masyarakat lokal sehari-hari bergantung pada sumber daya alam air tawar yang ada di Sungai Lenggang dan hutan kerangas di sekitarnya, kemudian pada tahun 2019 kelembagaannya menjadi Kelompok Sadar Wisata (Pokdarwis). Lanun Tebat Rasau yang diketuai oleh Nasidi dengan jumlah pengurus kurang lebih 20 orang.

Ekosistem air tawar dan hutan di Tebat Rasau, selain memiliki peranan penting bagi masyarakat, juga bisa menjadi laboraturium alam. Dari turun temurun masyarakat lokal telah memiliki pengetahuan memanfaatkan mengelola SDA di sana seperti cara menangkap ikan dan menggunakan tumbuhan sebagai rempah. Konsep Geopark kemuidian membantu menambah referensi ilmiah bahwa Sungai Lenggang menjadi habitat spesies primitif Asian Arowana (Scleropages formosus) yang memiliki nenek moyang ikan purba mengindikasikan jejak sungai purba pada sungai lenggang. Asian Arowana termasuk dalam spesies yang terancam punah dan masuk dalam IUCN Red List.

Nama Rasau sendiri diambil dari jenis tumbuhan pandan yang tumbuh pada rawa dan sungai. Selain itu, ekosistem hutan kerangas di sekitarnya juga menyimpan keunikan flora dan potensi obat herbal. Warisan geologi dan keanekaragaman hayati tersebut membantuk budaya masyarakat setempat yang tampak dari cara menangkap dan mengelola sumber daya alam di kawasan Tebat Rasau.

Lanun menawarkan jasa wisata dengan suguhan utama adalah wisata edukasi dan gastronomy. Wisatawan bisa bertamasya sekaligus menambah pengetahuan geologi, biodiversity dan kearifan lokal. Menu makan bedulang, minuman rempah teh sepang, teh pelawan dan kopi tanggar menjadi suguhan yang sangat menarik. Selain aktifitas tur, di Tebat Rasau juga diselenggarakan Sekolah Alam yang bertujuan mengenalkan anak-anak di sekitar tentang kekayaan alam 
agar menjaga alam Tebat Rasau terus berlangsung dari generasi ke generasi. Adapaun ringkasan profil umum Geosite yang menjadi lokasi penelitian dapat digambarkan dalam tabel sebagai berikut;

B. Cara komunitas membuat perencanaan untuk pengembangan Geosite. 1. Bentuk kegiatan atau forum yang digunakan.

Komunitas pengelola Geosite menggunakan media pertemuan, diskusi, kumpul, atau rapat. sebagai cara atau sarana dalam proses menyusun perencanaan suatu kegiatan. Sebagian besar pertemuan sudah dilaksanakan secara terjadwal, namun demikian masih terdapat pertemuan atau rapat yang belum terstruktur dengan baik, hal ini ditandai dengan ditemui fakta bahwa beberapa pertemuan masih bersifat spontan, kehadiran peserta rapat hanya orang-orang tertentu saja, dan sangat jarang membuat agenda rapat yang fokus terhadap kegiatan yang akan dilaksanakan. Komunitas Geosite yang kelembagaannya berbentuk Hutan Kemasyarakatan tampaknya lebih teratur dalam hal pelaksanaan pertemuan mengingat terdapat laporan kegiatan yang harus dilaporkan setiap akhir tahun (bulan Desember).

2. Cara pengambilan keputusan sebagai suatu kesepakatan bersama.

Komunitas memiliki dua cara dalam menuangkan hasil kesepakatan bersama yaitu, secara "lisan" dan secara "tertulis". Cara tertulis dilakukan dengan cara menuangkan seluruh hasil kesepakatan dalam bentuk berita acara, ataupun berupa notulen rapat yang disahkan dan ditandatangani oleh pimpinan rapat sedangkan cara lisan dilakukan dengan penyampaian hasil secara verbal dengan beberapa kata atau kalimat oleh pimpinan rapat yang disetujui oleh peserta rapat. Fakta lapangan menunjukan bahwa sebagian besar keputusan rapat dituangkan secara lisan.

3. Kriteria dokumen perencanaan yang dianggap sah dan mengikat seluruh anggota.

Diketahui bahwa jumlah komunitas yang menggunakan dokumen dengan kriteria tidak akuntabel lebih banyak sedikit dibandingkan yang menggunakan kriteria yang akuntabel dari total kegiatan pengambilan keputusan yang dilakukan oleh komunitas. Kategori yang akuntabel memiliki ciri, pertama; keputusan 
disampaikan dalam forum rapat, kedua; jika mayoritas peserta rapat setuju dan ketiga; mendapat pengesahan secara tertulis dari ketua komunitas, sedangkan kategori yang tidak akuntabel ditandai dengan, pertama; keputusan tidak perlu dituangkan dalam dokumen tertulis sepanjang diakui merupakan hasil kesepakatan bersama dalam rapat, kedua; keterwakilan jumlah peserta rapat tidak penting sepanjang pembahasan dilakukan oleh yang ahli atau menguasai permasalahan yang dibahas.

4. Keterlibatan masing-masing anggota komunitas.

Wujud keterlibatan anggota komunitas dalam penyusunan perencanaan pengembangan Geosite dilakukan tidak sepenuhnya mengikuti pembagian tugas yang tergambar dalam struktur organisasi. Ditemukan fakta bahwa sebagian besar keterlibatan anggota mulai dari mengusulkan ide atau gagasan sampai melaksanakan ide dan gagasan dimaksud tidak lagi merujuk pada tugas pokok dan fungsinya dalam struktur organisai, Siapapun berhak mengusulkan ide yang langsung dibahas dalam rapat anggota. Bahkan ditemukan bentuk partisipasi diluar struktur organisasi yang sudah disepakati. Oleh karena itu peneliti membagi bentuk partisipasi anggota dalam menyusun perencanaan kedalam dua model yaitu, model "struktural" dan model "fungsional". Model struktural dalam hal ini mengakomodasi gagasan dan partisipasi anggota mengikuti tugas pokok dan fungsinya (tupoksi) dalam struktur organisai meskipun dalam beberapa hal masih diberi peluang untuk mengusulkan hal atau ide lain diluar tupoksinya namun tanggungjawab utamanya tetap sesuai tupoksinya, sedangkan model fungsional adalah kebalikannya. Fakta lapangan menunjukan bahwa model fungsional lebih dominan dalam praktek penyaluran partisipasi anggota dalam perencanaan pengembangan Geosite.

5. Cara menemukan ide, gagasan, usulan yang disampaikan.

Komunitas memiliki keunikan dalam hal sumber ide dan gagasan dalam perencanan pengembangan Geosite. Penelitian ini menemukan dua kategori sumber ide atau gagasan yaitu, ide yang bersumber dari "Faktor Internal" dan ide yang bersumber dari "Faktor Eksternal". Faktor internal didefinisikan sebagai ide yang muncul dari pengetahuan sebagai akibat proses interaksi atau kegiatan anggota 
komunitas dilapangan tanpa ada campurtangan dari luar kegiatan komunitas. Sedangkan Faktor Eksternal didefinisikan sebagai ide yang muncul berdasarkan pengetahuan yang didapat dari luar kegiatan atau interaksi antar sesama anggota komunitas diluar Gesoite yang bersangkutan. Penelitian ini menemukan bahwa sebagian besar ide atau gagasan komunitas bersumber dari luar komunitas (Faktor Eksternal).

6. Dasar pertimbangan menerima atau menolak sebuah ide, usulan dan gagasan.

Dasar pertimbangan komunitas dalam menerima atau menolak sebuah ide, gagasan atau rencana kegiatan dibagi dalam dua kategori yaitu, yang berdasarkan alasan Rasional dan berdasarkan alasan yang tidak rasional (Irasional). Pertimbangan rasional didasarkan pada pengukuran kemampuan anggota komunitas baik dari segi pengetahuan, kekuatan jumlah anggota, maupun pengalaman terhadap ide yang ingin dilaksanakan, termasuk dalam hal ini pertimbangan kemampuan keuangan atau modal yang dimiliki. Pertimbangan Tidak Rasional biasanya berdasarkan pada hal-hal yang "diluar logika" namun sangat diyakini kebenarannya oleh sebagian besar anggota komunitas misalkan, berdasarkan masukan dari penasehat spiritual, tetua adat setempat, atau berdasarkan cerita mistis yang dipercaya oleh masyarakat sekitar.

7. Pembagian tugas khusus dan spesifik dalam penyusunan perencanaan.

Pembagian tugas secara khusus dan spesifik terhadap anggota dalam penyusunan perencanaan belum sepenuhnya dilaksanakan. Dalam hal ini masih ditemukan penyusunan perencanaan komunitas yang belum terorganisir dengan baik hal ini ditandai dengan adanya praktek memberi tugas kepada anggota yang sekedar bersedia dan menyangupi mengerjakan sesuatu saja, meski penunjukan yang bersangkutan tetap diputuskan dalam rapat atau pertemuan. Dalam kasus yang lain bahkan tidak ada pembagian tugas sama sekali, masing-masing anggota ikut mengerjakan secara gotong royong atau memiliki tugas dan tanggung jawab yang sama mulai dari perencanaan sampai kepada pelaksanaan kegiatan dilapangan. Namun demikian sebagian besar komunitas masih mampu melaksanakan kegiatan perencanaan dengan lebih baik atau lebih terorganisir, yang ditandai dengan sudah 
adanya pembagian tugas mengikuti struktur atau tupoksi yang ada serta pebagian tugas yang mendasarkan kepada keahlian atau keterampilan yang dimiliki oleh anggota yang bersangkutan.

8. Mekanisme penyelesaian konflik jika terdapat perbedaan pendapat.

Saat terjadi konflik yang dalam hal ini terdapat perbedaan pendapat antar anggota komunitas sebagian besar diselesaiakan secara kekeluargaan. Dalam hal ini sangat jarang ditemui penyelesaian konflik melalui mekanisme organisasi yang dalam kasus ini berpeluang terjadi pada komunitas yang bersatus sebagai HKm, dimana telah diatur hak dan kewajiban anggota serta persyaratan sebagai anggota, hal ini tidak berlaku untuk komunitas yang sejarah terbentuknya sejak awal memang berdasar semangat kesamaan visi terhadap persoalan yang dihadapi oleh komunitas. Berdasarkan fakta yang ditemui di lapangan terdapat fakta bahwa sebagian besar cara penyelesaian konflik dilakukan dengan mekanisme kekeluargaan.

9. Keterlibatan pihak lain diluar anggota komunitas.

Keterlibatan pihak diluar anggota komunitas memiliki pengaruh besar terhadap proses perencanaan pengembangan Geosite. Berdasarkan fakta lapangan diketahui bahwa sebagian besar perencanaan dipengaruhi oleh pihak luar yang dalam hal ini terdiri dari ; 1) masyarakat/pemuda disekitar lokasi Geosite yang tertarik dengan kegiatan komunitas, 2) Tokoh masyarakat setempat atau tetua adat, 3) Pelaku wisata yang berkunjung (TA/TO) 4) Komunitas pecinta alam, 5) Perusahaan atau Badan Usaha sekitar lokasi Geosite (se Pulau Belitung), 6) Instansi Pemerintah Daerah dan Provinsi (termasuk penyuluh dan pendamping HKM), 7) Komunitas HKM lain baik dari dalam maupun luar Pulau Belitung. Pengaruh pihak diluar komunitas dimaksud berpengaruh sangat signifikan terhadap proses perencanaan pengembangan Geosite yang dilakukan oleh Komunitas, meskipun dalam praktek mereka tidak secara langsung ikut campur dalam perencanaan ataupun usulan kegiatan yang akan dilakukan oleh komunitas, namun kehadiran mereka banyak memberikan pengetahuan baru kepada anggota komunitas yang sebagian besarnya memang memiliki lingkup pergaulan yang sangat terbatas terhadap lingkungan diluar lokasi Geosite atau tempat tinggal mereka. 


\section{Bentuk keterlibatan komunitas dalam membuat perencanaan untuk pengembangan Geosite.}

1. Cara menyampaikan ide, gagasan dan usulan.

Cara yang dilakukan oleh anggota komunitas dalam menyampaikan ide, gagasan, atau usulan perencanaan untuk pengembangan Geosite umumnya disampaikan secara lisan, namun demikian forum yang digunakan ada yang disampaikan dalan forum rapat atau pertemuan yang memang khusus direncanakan untuk membahas kegiatan yang akan dilaksanakan dan ada juga cara lain yaitu secara spontan dalam obrolan santai ataupun diskusi dengan sesama anggota komunitas yang secara kebetulan memang memiliki kebiasaan berkumpul setiap ada kesempatan atau mengisi waktu senggang. Sehingga ditemukan dua pola atau bentuk penyampaian ide atau gagasan dalam hal ini yaitu pola yang "terorganisir" dan pola yang "tidak terorganisir". Pola terorganisir ditandai dengan adanya penjadwalan pertemuan atau rapat yang memang khusus untuk membicarakan tentang rencana kegiatan kedepan, baik rencana kerja mingguan, bulanan maupun tahunan, bahkan seluruh hasil pembahasan dituangkan secara tertulis dalam bentuk berita acara maupun notulen rapat yang disahkan oleh ketua komunitas atau pimpinan rapat. Sedangkan pola yang tidak terorganisir adalah sebaliknya. Dalam penelitian ini ditemukan fakta bahwa sebagian besar penyampaian ide atau gagasan oleh komunitas sudah teroganisir dengan baik.

2. Sikap jika usulan, ide, gagasan yang diajukan diabaikan atau tidak diakomodir.

Dalam hal ide atau gagasan yang diusulkan ternyata tidak diakomodir dalam keputusan rapat atau ditolak, sebagian besar anggota komunitas tidak mempermasalahkannya, dalam hal ini seluruh anggota menyikapi dengan sikap positif dalam artian tidak menunjukan sikap kecewa atau protes secara berlebihan. Namun demikian beberapa anggota komunitas tetap meminta penjelasan atau alasan penolakan atas usulannya tersebut. Sebagiannya lagi mengambil sikap menerima keputusan Bersama tanpa mengajukan keberatan sama sekali dan cenderung diam atau pasrah. Berdasarkan interview yang dilakukan didapati fakta 
bahwa seluruh anggota komunitas memberikan respons secara positif atas penolakan terhadap ide yang disampaikan. Penelitian juga menemukan beberapa hal yang menjadi alasan penolakan terhadap ide yang disampaikan yaitu, lebih banyak disebabkan atas pertimbangan kemampuan sumberdaya yang dimiliki baik sumberdaya anggota maupun sumberdaya keuangan yang dimiliki.

3. Keterlibatan dan partisipasi anggota dalam setiap tahapan sampai ditetapkan.

Partisipasi dan keterlibatan anggota komunitas dalam proses perencanaan merupakan partisipasi yang tinggi. Hal ini ditunjukan dengan bukti bahwa seluruh anggota memiliki komitmen yang kuat terhadap usulan yang telah disepakati dalam pertemuan atau rapat, artinya seluruhnya berupaya terlibat sejak proses awal sampai selesainya kegiatan yang telah ditetapkan tersebut. Sangat jarang ditemui kasus adanya anggota yang secara sengaja tidak mau terlibat dalam kegiatan-kegiatan yang sudah direncanakan Bersama. Seluruh tahapan mulai dari perencanaan, pelaksanaan sampai evaluasi atas kegiatan selalu diikuti oleh sebagian besar anggota komunitas sesuai kapasitas masing-masing.

4. Cara melakukan evaluasi terhadap perencanaan.

Komunitas memiliki cara masing-masing dalam melakukan evaluasi terhadap perencanaan yang sedang, telah dan akan dilaksanakan. Peneliti membagi dua kategori dalam evaluasi terhadap perencanaan yang telah ditetapkan, yaitu "Evaluasi Terstruktur" dan "Evaluasi Tidak Terstruktur”. Sebagian komunitas sudah melaksanakan mekanisme evaluasi sebagai mana seharusnya hal ini ditandai dengan ditemuinya fakta bahwa, 1) Komunitas memiliki agenda rutin yang secara teratur digelar komunitas untuk melakukan evaluasi terhadap perencanaan yang telah ditetapkan, 2) Beberapa kasus evaluasi telah dilakukan secara serius bahkan sampai pada tingkat penghentian kegiatan dan penggantian petugas pelaksana 3) Beberapa komunitas Geosite bahkan memiliki instrumen yang akan digunakan untuk melakukan evaluasi karena sebagian besar hasil rapat telah dibuat dalam bentuk tertulis, 4) Beberapa kasus yang terjadi menggambarkan setiap terjadi kesalahan dalam pelaksanaan yang mengakibatkan target tidak tercapai, maka yang diganti adalah orang atau pelaksananya sementara target tetap tidak diubah, 5) 
Seluruh anggota memiliki kewajiban yang sama dalam hal kontrol dan pengawasan, sehingga memperkecil kemungkinan terjadinya kesalahan dalam pelaksanaan dilapangan.

5. Jika pelaksanaan kegiatan tidak sesuai dengan perencanaan.

Dalam hal ditemui keadaan pelaksanaan kegiatan yang tidak sesuai dengan rencana, sebagian besar anggota komunitas mampu menyikapi dengan baik, sehingga dapat dikategorikan sebagai sikap atau tindakan yang "Responsif" (bertanggungjawab). Hal ini ditandai dengan tindakan-tindakan antisipasi yang dilakukan antara lain; 1) Langsung berupaya mengatasi atau berupaya mencari solusi terhadap kesalahan yang terjadi dilapangan tanpa menimbulkan konflik, 2) selalu berkoordinasi kepada ketua komunitas atau anggota yang lain sebelum mengambil tindakan lapangan, 3) berupaya melakukan konfirmasi dan memastikan dengan memeriksa dokumen perencanaan yang ada, 4) Mengadakan monitoring pelaksanaan kegiatan dilapangan secara bersama-sama secara terus menerus meskipun tidak ada penunjukan secara khusus.

\section{Kualitas pemahaman komunitas tentang Geopark dan peran Geosite yang dimiliki.}

1. Bagaimana, kapan dan apa yang diketahui tetang Geopark.

Masing-masing anggota komunitas memiliki sumber informasi dan kedalaman pengetahuan tentang Geopark berbeda satu dengan yang lain. Namun peneliti membagi dua kategori sumber informasi atau pengetahuan tentang Geopark, yaitu "sumber resmi" dan "bukan sumber resmi”. Sumber resmi adalah informasi atau pengetahuan yang berasal dari pihak-pihak yang secara individu maupun kelembagaan resmi termasuk dalam pengelolaan Geopark Belitong, misalkan Badan Pegelola Geopark Belitong, termasuk dalam hal ini sumber informasi yang berasal dari instansi pemerintah yang benar-benar terlibat dalam pengelolaan Geopark, misalkan Kementrian Perencanaan Pembangunan Nasional, Kementrian Pariwisata, Kementrian ESDM, Kemendikbud, Badan Geologi, Kemenkomarves) atau lembaga lain yang memiliki mandat dan tugas untuk pengelolaan Geopark baik secara Lokal, Nasional maupun Global (UNESCO 
Global Geopark, GGN, KNGI, JGI, dst). Sedangkan sumber bukan resmi merupakan pihak-pihak yang secara individu maupun kelembagaan tidak memiliki tugas dan wewenang dalam penggelolaan dan pengembangan Geopark Belitong. Berdasarkan fakta lapangan diketahui bahwa sebagian besar anggota komunitas memperoleh pengetahuan dari sumber informasi resmi tentang Geopark, sedangkan sisanya memperoleh informasi bukan berasal dari sumber resmi, dalam hal ini informasi diperoleh dari individu atau Lembaga yang mengatasnamakan penggiat Geopark Belitong, walaupun dalam kenyataannya tidak demikian.

2. Pengetahuan tentang warisan geologi, biologi, budaya yang ada di Geosite.

Pengetahuan anggota komunitas tentang warisan Geologi, Biologi, Budaya yang dimiliki di Geosite masing-masing, masih cukup beragam, namun peneliti membaginya dalam dua kategori pertama; "cukup memahami”, kedua "kurang memahami”. Berdasarkan fakta yang didapat diketahui bahwa sebagian anggota komunitas kurang memahami tentang warisan Geologi, Biologi dan Budaya yang dimilikinya, kemudian sisanya dinilai cukup memahami tentang warisan Geologi, Biologi dan Budaya yang dimiliki di Geosite yang bersangkutan. Pengetahuan ini jika ditelusuri lebih dalam sebagian besar dipengaruhi oleh faktor posisi atau kedudukan yang bersangkutan dalam komunitas, dalam hal ini hampir seluruh ketua dan pengurus senior memiliki pengetahuan yang cukup memadai tentang Geopark serta manfaatnya bagi masyarakat sekitarnya bahkan untuk masyarakat secara luas. 3. Perubahan atau dampak yang dirasakan saat sebelum dan setelah ditetapkan sebagai Geosite.

Hampir seluruh anggota komunitas mengakui bahwa telah terjadi perubahan yang sangat signifikan saat sebelum dan setelah lokasi mereka ditetapkan sebagai Geosite. Perubahan yang disampaikan misalnya terkait banyaknya infrastruktur penunjang baik berupa, jalan, WC, tempat sampah, sign board, listrik, mushola, dan lain sebagainya. Selain itu semakin banyak kegiatan penelitian dan pengabdian masyarakat dari berbagai kampus, serta semakin banyak kunjungan turis atau wisatawan ke Geosite termasuk wisatawan lokal yang juga semakin antusias berkunjung ke Geosite-Geosite. 
4. Pedoman atau rujukan yang digunakan untuk memandu seluruh kegiatan pengelolaan Geosite.

Terkait dengan pedoman dan rujukan anggota komunitas dalam memandu seluruh pengelolaan Geosite, yaitu pedoman untuk menentukan apa yang boleh dan tidak terkait kegiatan pengelolaan Geosite, peneliti membaginya kedalam dua kategori yaitu pedoman atau rujukan "resmi" dan "Pedoman Adat setempat". Dalam hal ini sebagian besar anggota komunitas menggunakan infromasi resmi sebagai pedoman atau rujukan dalam pengelolaan Geosite, baik berupa SOP, Peta Kawasan, Peraturan Kementrian terkait, Struktur Organisasi, dan lain sebagainya. Sedangkan sisanya masih mengandalkan aturan dan kebiasaan adat setempat sebagai pedoman acuan dalam melaksanakan kegiatan pengembangan Geosite.

5. Dokumen perencanaan dengan tingkatan yang lebih tinggi sebagai acuan dalam menyusun perencanaan.

Sebagian besar anggota komunitas tidak mengetahui tentang dokumen perencanaan dengan tingkatan yang lebih tinggi yang dijadikan acuan yang harus diikuti dalam menyusun perencanaan pengembangan Geosite. Fakta menunjukan bahwa lebih dari separuh anggota komunitas menyatakan belum mengetahui atau menyatakan tidak ada acuan dimaksud, mereka selama ini mengacu kepada peraturan Pemerintah yang bersifat umum, namun tidak terkait langsung dengan pengelolaan Geositenya, misalkan peraturan tindak pidana, perdata, dan lain sebagainya. Sedangkan sisanya sebesar $44.44 \%$ mengaku mengetahui jika ada pedoman yang menjadi rujukan dalam menyusun perencanaan yang harus diikuti sebagai acuan yang lebih tinggi baik itu berupa Peraturan Menteri (misalkan Permen Kehutanan nomor 83 tahun 2016 untuk acuan HKm) serta berdasarkan Masterplan yang telah ditetapkan.

6. Ketentuan atau peraturan yang mengikat dan harus dipatuhi dalam pengembangan Geosite.

Terdapat beberapa jenis aturan dan ketentuan yang menjadi acuan komunitas yang terdiri dari : 1) aturan adat setempat, 2) aturan Umum Pemerintah, 3) AD/ART organisasi, 4) Standar Operasional dan Prosedur (SOP), 5) Peraturan Menteri/Pemerintah. Namun secara garis bersar dapat dikelompokan menjadi dua 
kategori yaitu aturan yang bersifat "formal" dan aturan "Non formal". Dalam hal ini sebagian besar anggota komunitas mengacu kepada aturan formal dalam menjalankan kegiatannya dan sisanya lebih mengacu kepada aturan yang bersifat non formal.

7. Pengetahuan tentang peran Geosite yang dikelola dalam pengembangan Geopark.

Sebagian besar anggota komunitas memahami tentang peran penting Geosite yang mereka miliki terhadap pengembangan Geopark Belitong secara keseluruhan. Sehingga dalam hal ini peneliti membagi kedalam dua kategori yaitu, anggota komunitas yang "sangat memahami” dan yang "kurang memahami”. Fakta menunjukan bahwa sebagian besar anggota komunitas sangat memahami tentang peran penting Geosite mereka.

\section{KESIMPULAN}

Berdasarkan hasil penelitian dapat disimpulkan bahwa secara umum komunitas pengelola Geopark memiliki kemampuan dalam menyusun dan merumuskan perencanaan untuk pengembangan Geosite dalam rangka pengembangan Geopark Belitong, sehingga layak untuk dijadikan partner dalam penyusunan perencanaan pengembangan Geopark dengan asumsi capaian nilai total berdasar analisis skala pembobotan sebesar 73,21\% (tujuh puluh tiga koma dua puluh satu persen). Penjelasan atas kesimpulan tersebut dapat diuraikan lebih lanjut menggunakan tabel analisa skala pembobotan (Weighted Scale Analysis), sebagaimana tabel berikut; 
Tabel. 1.

Analisis Skala Pembobotan (Weighted Scale Analysis) terhadap

Cara Penyusunan Perencanaan, Bentuk Partisipasi Perencanaan dan

Pengetahuan tentang Geopark

\begin{tabular}{|c|c|c|c|c|c|c|c|c|}
\hline & \multirow[b]{2}{*}{ Definisi Operasional Konsep } & \multicolumn{2}{|c|}{ Kategori } & \multicolumn{2}{|c|}{$\begin{array}{l}\text { Bobot } \\
\text { Angka }\end{array}$} & \multicolumn{2}{|c|}{ Persentase } & \multirow{2}{*}{$\begin{array}{l}\text { Kesimp } \\
\text { ulan } \\
\text { Makna }\end{array}$} \\
\hline & & $\begin{array}{l}\text { Makna } \\
\text { Positif } \\
\text { (MP) }\end{array}$ & $\begin{array}{l}\text { Makna } \\
\text { Negatif } \\
\text { (MN) }\end{array}$ & MP & $\mathbf{M N}$ & MP & MN & \\
\hline $\mathbf{A}$ & \multicolumn{8}{|c|}{ Cara komunitas menyusun perencanaan } \\
\hline 1 & $\begin{array}{l}\text { Bentuk kegiatan atau forum } \\
\text { yang digunakan dalam proses } \\
\text { penyusunan perencanaan }\end{array}$ & Terstruktur & $\begin{array}{c}\text { Tidak } \\
\text { Terstruktur }\end{array}$ & 14 & 2 & 87,50 & 12,50 & Positif \\
\hline 2 & $\begin{array}{l}\text { Cara pengambilan keputusan } \\
\text { sebagai suatu kesepakatan } \\
\text { bersama dalam menyusun } \\
\text { perencanaan }\end{array}$ & Tertulis & Lisan & 2 & 6 & 25,00 & 75,00 & Negatif \\
\hline 3 & $\begin{array}{l}\text { Kriteria dokumen perencanaan } \\
\text { yang dianggap sah dan } \\
\text { mengikat seluruhanggota } \\
\text { atau kegiatan organisasi }\end{array}$ & Akuntabel & $\begin{array}{c}\text { Tidak } \\
\text { Akuntabel }\end{array}$ & 7 & 8 & 46,67 & 53,33 & Negatif \\
\hline 4 & $\begin{array}{l}\text { Keterlibatan masing-masing } \\
\text { anggota komunitas dalam } \\
\text { penyusunan } \\
\text { dokumen perencanaan }\end{array}$ & Fungsional & Struktural & 13 & 3 & 81,25 & 18,75 & Positif \\
\hline 5 & $\begin{array}{l}\text { Cara menemukan ide, gagasan, } \\
\text { usulan yang disampaikan } \\
\text { dalam tahapan perencanaan }\end{array}$ & Eksternal & Internal & 10 & 6 & 62,50 & 37,50 & Positif \\
\hline 6 & $\begin{array}{l}\text { Dasar pertimbangan untuk } \\
\text { menerima, mempertimbangkan } \\
\text { dan menolak sebuah } \\
\text { ide, usulan, gagasan }\end{array}$ & Rasional & $\begin{array}{c}\text { Tidak } \\
\text { Rasional }\end{array}$ & 12 & 3 & 80,00 & 20,00 & Positif \\
\hline 7 & $\begin{array}{l}\text { Pembagian tugas khusus dan } \\
\text { spesifik dalam penyusunan } \\
\text { perencanaan }\end{array}$ & Terorganisir & $\begin{array}{c}\text { Belum } \\
\text { Terorganisir }\end{array}$ & 10 & 6 & 62,50 & 37,50 & Positif \\
\hline 8 & $\begin{array}{l}\text { Mekanisme penyelesaian } \\
\text { konflik jika terdapat perbedaan } \\
\text { pendapat }\end{array}$ & Kekeluargaan & Organisasi & 13 & 3 & 81,25 & 18,75 & Positif \\
\hline \multirow[t]{2}{*}{9} & $\begin{array}{l}\text { Keterlibatan pihak lain diluar } \\
\text { anggota komunitas dalam } \\
\text { proses } \\
\text { penyusunan perencanaan }\end{array}$ & Signifikan & Tidak Ada & 11 & 3 & 78,57 & 21,43 & Positif \\
\hline & & & Jumlah A = & 92 & 40 & 69,70 & 30,30 & Positif \\
\hline B & \multicolumn{8}{|c|}{ Bentuk-bentuk partisipasi komunitas dalam penyusunan perencanaan } \\
\hline 1 & $\begin{array}{l}\text { Cara menyampaikan ide, } \\
\text { gagasan, usulan dalam } \\
\text { perencanaan }\end{array}$ & Terorganisir & $\begin{array}{c}\text { Tidak } \\
\text { Terorganisir }\end{array}$ & 9 & 3 & 75,00 & 25,00 & Positif \\
\hline 2 & $\begin{array}{l}\text { Sikap jika usulan, ide, gagasan } \\
\text { yang diajukan diabaikan atau } \\
\text { tidak diakomodir } \\
\text { dalam proses perencanaan }\end{array}$ & $\begin{array}{l}\text { Sikap } \\
\text { Positif }\end{array}$ & $\begin{array}{c}\text { Sikap } \\
\text { Negatif }\end{array}$ & 16 & 0 & 100 & 0,00 & Positif \\
\hline 3 & $\begin{array}{l}\text { Keterlibatan dan partisipasi } \\
\text { dalam setiap tahapan } \\
\text { perencanaan sampai ditetapkan }\end{array}$ & $\begin{array}{l}\text { Partisipasi } \\
\text { Tinggi }\end{array}$ & $\begin{array}{l}\text { Partisipasi } \\
\text { Rendah }\end{array}$ & 16 & 0 & 100 & 0,00 & Positif \\
\hline
\end{tabular}




\begin{tabular}{|c|c|c|c|c|c|c|c|c|}
\hline 4 & $\begin{array}{l}\text { Cara melakukan evaluasi } \\
\text { terhadap perencanaan yang } \\
\text { akan, sedang dan } \\
\text { akan dilaksanakan } \\
\end{array}$ & $\begin{array}{c}\text { Evaluasi } \\
\text { Terstruktur }\end{array}$ & $\begin{array}{c}\text { Tidak } \\
\text { Terstruktur }\end{array}$ & 8 & 6 & 57,14 & 42,86 & Positif \\
\hline \multirow[t]{2}{*}{5} & $\begin{array}{l}\text { Apa yang dilakukan jika } \\
\text { ditemui suatu pelaksanaan } \\
\text { kegiatan yang tidak } \\
\text { sesuai dengan perencanaan } \\
\text { yang telah disepakati }\end{array}$ & Responsif & Reaktif & 11 & 4 & 73,33 & 26,67 & Positif \\
\hline & & & Jumlah B = & 60 & 13 & 82,19 & $\mathbf{1 7 , 8 1}$ & Positif \\
\hline $\mathbf{C}$ & \multicolumn{8}{|c|}{ Pengetahuan komunitas tentang Geopark dan peran Geosite yang dimiliki } \\
\hline 1 & $\begin{array}{l}\text { Bagaimana, kapan dan apa yang } \\
\text { diketahui tetang Geopark }\end{array}$ & $\begin{array}{l}\text { Sumber } \\
\text { Resmi }\end{array}$ & $\begin{array}{c}\text { Sumber } \\
\text { Tidak Resmi }\end{array}$ & 12 & 4 & 75,00 & 25,00 & Positif \\
\hline 2 & $\begin{array}{l}\text { Pengetahuan tentang warisan } \\
\text { geologi/biologi/budaya yang } \\
\text { ada di Geosite }\end{array}$ & $\begin{array}{c}\text { Cukup } \\
\text { Memahami }\end{array}$ & $\begin{array}{c}\text { Kurang } \\
\text { Memahami }\end{array}$ & 4 & 4 & 50,00 & 50,00 & Positif \\
\hline 3 & $\begin{array}{l}\text { Perubahan atau dampak yang } \\
\text { dirasakan saat sebelum dan } \\
\text { setelah ditetapkan } \\
\text { sebagai Geosite }\end{array}$ & $\begin{array}{l}\text { Perubahan } \\
\text { Positif }\end{array}$ & $\begin{array}{l}\text { Tidak Ada } \\
\text { Perubahan }\end{array}$ & 12 & 1 & 92,31 & 7,69 & Positif \\
\hline 4 & $\begin{array}{l}\text { Pedoman atau rujukan yang } \\
\text { digunakan untuk memandu } \\
\text { seluruh kegiatan } \\
\text { pengelolaan Geosite }\end{array}$ & $\begin{array}{l}\text { Pedoman } \\
\text { Resmi }\end{array}$ & $\begin{array}{c}\text { Adat } \\
\text { Setempat }\end{array}$ & 7 & 3 & 70,00 & 30,00 & Positif \\
\hline 5 & $\begin{array}{l}\text { Dokumen perencanaan dengan } \\
\text { tingkatan yang lebih tinggi } \\
\text { sebagai acuan dalam } \\
\text { menyusun seluruh perencanaan }\end{array}$ & $\begin{array}{l}\text { Ada Acuan } \\
\text { Khusus }\end{array}$ & $\begin{array}{l}\text { Belum Ada } \\
\text { Acuan }\end{array}$ & 4 & 5 & 44,44 & 55,56 & Negatif \\
\hline 6 & $\begin{array}{l}\text { Ketentuan atau peraturan yang } \\
\text { mengikat dan harus dipatuhi } \\
\text { dalam } \\
\text { pengembangan Geosite }\end{array}$ & Formal & Non Formal & 7 & 3 & 70,00 & 30,00 & Positif \\
\hline \multirow[t]{3}{*}{7} & $\begin{array}{l}\text { Pengetahuan tentang } \text { peran } \\
\text { Geosite yang dikelola dalam } \\
\text { pengembangan Geopark }\end{array}$ & $\begin{array}{c}\text { Sangat } \\
\text { Memahami }\end{array}$ & $\begin{array}{c}\text { Kurang } \\
\text { Memahami }\end{array}$ & 7 & 2 & 77,78 & 22,22 & Positif \\
\hline & & & Jumlah C = & 53 & 22 & 70,67 & 29,33 & Positif \\
\hline & & Jum & h $A+B+C=$ & 205 & 75 & 73,21 & 26,79 & Positif \\
\hline
\end{tabular}

Untuk memperjelas hasil sekaligus menjawab tiga pertanyaan penelitian maka dapat dijelaskan kesimpulan hasil penelitian sebagai berikut;

a. Cara komunitas menyusun perencanaan

Hasil penelitian menyimpulkan bahwa "cara komunitas menyusun perencanaan" termasuk dalam kategori "baik" karena memperoleh nilai "positif" sebesar 69,70\% (enam puluh Sembilan koma tujuh puluh persen). Walaupun demikian capaian tersebut belum cukup meyakinkan jika dibanding nilai maksimal yang masih dapat dicapai (100\%). Hal ini berarti tingkat kemampuan komunitas dalam menyusun perencanaan, masih perlu ditingkatkan. Selain itu terdapat hal yang perlu mendapat perhatian serius yaitu, masih terdapat nilai "negatif" terhadap 
"cara pengambilan keputusan sebagai suatu kesepakatan bersama dalam menyusun perencanaan", dimana ditemui fakta sebanyak 75\% (tujuh puluh lima persen) cara pengambilan keputusan dalam rapat dilakukan secara "lisan" atau tidak dituangkan secara tertulis baik dalam bentuk Notulen maupun Berita Acara Rapat. Hal ini tentu sangat "menghawatirkan" mengingat resiko-resiko yang dapat ditimbulkan karena kemampuan daya ingat yang terbatas atau berbeda antar anggota komunitas sehingga sangat berpotensi menimbulkan konflik internal. Selain itu, sebagai Geosite yang potensial untuk dikembangkan di masa mendatang, tentu akan menghadapi situasi yang semakin kompleks terhadap kegiatan-kegiatan yang akan dihadapi termasuk keterlibatan berbagai pihak diluar komunitas yang pastinya akan sangat membutuhkan dukungan data atau dokumen tertulis khusnya terhadap perencanaan pengembangan Geosite yang telah disusun komunitas sebagai bahan pertimbangan untuk mengambil keputusan terhadap kerjasama-kerjasama yang akan dilakukan. Walaupun seluruh keputusan lisan tersebut sejauh ini dimaknai oleh anggota komunitas sebagai suatu keputusan yang sah dan mengikat seluruh anggota.

Selain itu, masih terdapat penilaian "negatif” terhadap kriteria dokumen perencanaan yang dianggap sah, dalam hal ini masih didominasi kategori "tidak akuntabel" sebesar 53,33\% (lima puluh tiga koma tiga puluh tiga persen) dibanding kategori "akuntabel" yang hanya sebesar 46,67\% (empat puluh enam koma enam puluh tujuh persen). Dalam hal ini masih banyak anggota komunitas yang beranggapan bahwa keputusan tidak perlu dituangkan dalam dokumen tertulis sepanjang diakui merupakan hasil kesepakatan bersama dalam rapat anggota, selain itu keterwakilan jumlah peserta rapat juga dianggap tidak terlalu penting sepanjang pembahasan dilakukan oleh yang ahli atau menguasai permasalahan yang dibahas. Dalam beberapa kasus sangat terlihat dominasi ketua komunitas atau beberapa pengurus "senior" terhadap pengambilan keputusan. Alasan lain terjadinya hal tersebut adalah untuk lebih mempercepat pengambilan keputusan serta karena rasa saling percaya dan kekeluargaan yang sangat tinggi antar sesama anggota komunitas sehingga cenderung tidak mempermasalahkan proses tersebut.

b. Bentuk-bentuk partisipasi komunitas dalam penyusunan perencanaan 
Dengan perolehan nilai akumulatif sebesar 82,19\% (delapan puluh dua koma Sembilan belas persen) maka penilaian terhadap partisipasi komunitas dalam penyusunan pererncanaan adalah "positif" sehingga dapat disimpulkan bahwa tingkat partisipasi komunitas dalam penyusunan perencanaan sudah sangat memadai dan meyakinkan. Hal ini disebabkan karena komunitas memiliki rasa kebersamaan dan kekeluargaan yang sangat tinggi sehingga cenderung memiliki visi dan misi yang sama terhadap lingkungan maupun Geosite yang dikelolanya selain itu sangat jarang terjadi konflik atau perselisihan antar anggota komunitas terkait penyampaian ide dan gagasan dalam penyusunan perencanaan, hampir seluruh anggota memiliki sikap yang "positif” dalam menghadapi setiap konflik atau perselisihan yang terjadi, termasuk tingkat partisipasi atau kehadiran anggota komunitas yang juga sangat tinggi. Meskipun demikian masih perlu ditingkatkan lagi kualitas partisipasi dimaksud, dari "sekedar" aktif secara kuantitas atau kehadiran dalam pertemuan, menjadi partisipasi yang lebih "berkualitas" yang dalam hal ini secara substansi benar-benar memberikan kontribusi yang besar terhadap gagasan pengembangan Geosite.

c. Pengetahuan komunitas tentang Geopark dan peran Geosite yang dimiliki

Berdasarkan capaian nilai akumulatif sebesar 70,67\% (tujuh puluh koma enam puluh tujuh persen) maka dapat disimpulkan bahwa komunitas secara mayoritas sudah memiliki pengetahuan yang baik tentang "makna Geopark serta peran Geositenya dalam pegembangan Geopark Belitong", namun demikian masih perlu ditingkatkan sampai ke level nilai yang lebih meyakinkan. Selain itu terdapat definisi operasional konsep yang masih bernilai "negatif" yaitu, terhadap penilaian "pengetahuan komunitas terhadap dokumen perencanaan dengan tingkatan yang lebih tinggi sebagai acuan dalam menyusun perencanaan pengembangan Geosite”, karena sebagian besar komunitas masih belum memahami tentang adanya dokumen perencanaan berupa "masterplan", maupun dokumen lain yang "seharusnya" menjadi acuan komunitas dalam pengembangan Geositenya. Misalkan aturan pemerintah terkait Geopark (Perpres Nomor 9 Tahun 2019 tentang Pengembangan Taman Bumi), Dossier Usulan Geoaprk Belitong untuk menjadi angggota UGGp, Masterplan Geopark Belitong, maupun Rencana Aksi Nasional Geopark yang telah 
dirumuskan. Dalam hal ini kurangnya pengetahuan terkait hal tersebut ditambah belum adanya kesadaran bahwa Geosite sendiri merupakan bagian dari perencanaan pengembangan Geopark Belitong bahkan bagian dari pengembangan Geopark Nasional dan Global.

\section{DAFTAR PUSTAKA}

Anze Chen, Y. L. (2015). The Principles of Geotourism. Beijing: Science Press, Beijing.

Badan Pengelola Geopark Belitong. (n.d.). Gesosite Map. Retrieved Maret 12, 2020, from belitonggeopark: https://belitonggeopark.net/map-2

Bihamding, H. (2019). Perencanaan Pembangunan Partisipatif Desa. Yogyakarta: Deepublish Publisher.

GEA Institut Teknologi Bandung. (2017). Explore The Unexplored. Bandung: Bidang Media Komunikasi dan InformaBidang Media Kominfo Hima Teknik Geologi "GEA" Institut Teknologi Bandung.

Hiriansah, M. M. (2019). Metodologi Penelitian, Suatu Tinjauan Konsep dan Konstruk. (Dema, Ed.) Pasuruan: Qiara Media Partner.

Komite Nasional Indonesia Untuk UNESCO. (n.d.). kniu.kemdikbud. Retrieved februari 15, 2020, from UNESCO Global Geopark (UGG): https://kniu.kemdikbud.go.id/?page_id=492

Marakas, G. M. (2003). Decision Support Systems in The 21 st Century Second Edition. New Jersey: Prentice Hall.

Samodra, H. (2012, Januari 29). Konsep Geopark. Retrieved Januari 26, 2020, from rusnapermadi: https://rusnapermadi.wordpress.com/2012/01/29/konsepgeopark/

Siyoto, S. (2015). Dasar Metodologi Penelitian. Yogyakarta: Literasi Media Publishing.

Sosiologis.com. (2018, Juni 22). Teknik Analisis Data Kualitatif: Contoh \& Prosesnya. Retrieved from sosiologis.

UNESCO Global Geopark. (2017). Earth Sciences. Retrieved from unesco.org: http://www.unesco.org/new/en/natural-sciences/environment/earthsciences/unesco-global-geoparks/top-10-focus-areas/ 
UNESCO Global Geoparks. (2017). Earth Science for Society. Retrieved Mei 15, 2020, from uneco.org: http://www.unesco.org/new/en/naturalsciences/environment/earth-sciences/unesco-global-geoparks/frequentlyasked-questions/what-is-a-unesco-global-geopark/

Utarini, A. (2020). Tak Kenal Maka Tak Sayang: Penelitian Kualitatif dalam Pelayanan Kesehatan. (Galih, Ed.) Yogyakarta: Gajah Mada University Press.

Widi, R. K. (2018). Menggelorakan Penelitian; Pengenalan dan Penuntun Pelaksanaan Penelitian. Yogyakarta: Deepublish. Retrieved from www.penerbitdeepublish.com 